\title{
Opini Audit Pemoderasi Pengaruh Profitabilitas, Ukuran Perusahaan, Kepemilikan Institusional, dan Komite Audit Terhadap Ketepatanwaktuan
}

\author{
Fadhli Azhari ${ }^{1}$ \\ Muhammad Nuryatno ${ }^{2}$ \\ ${ }^{1,2}$ Fakultas Ekonomi dan Bisnis, Universitas Trisakti, Indonesia \\ email: fadhliazhari06@gmail.com
}

DOI: https://doi.org/10.24843/JIAB.2019.v14.i01.p03

\section{Jurnal Ilmiah Akuntansi dan Bisnis (JIAB)}

https://ojs.unud.ac.id/index.php/jiab/ user/profile

Volume 14

Nomor 1

Januari 2019

Halaman 19-33

p-ISSN $\underline{2302-514 X}$

e-ISSN $\underline{2303-1018}$

\section{INFORMASI ARTIKEL}

Tanggal masuk: 29 Agustus 2018

Tanggal revisi:

24 Desember 2018

Tanggal diterima:

02 Januari 2019

\begin{abstract}
ABSTRAK
Penelitian bertujuan mengetahui peran opini audit sebagai pemoderasi pengaruh profitabilitas, ukuran perusahaan, kepemilikan institusional, dan komite audit terhadap ketepatan waktu pelaporan keuangan pada perusahaan manufaktur terdaftar di Bursa Efek Indonesia periode tahun 2012 sampai dengan 2016. Metode pengambilan sampel yang digunakan adalah metode purposive sampling, sehingga diperoleh 96 perusahaan manufaktur. Teknik analisis data yang digunakan adalah menggunakan regresi logistik. Hasil pengujian menunjukkan bahwa profitabilitas dan ukuran perusahaan berpengaruh positif terhadap ketepatan waktu pelaporan keuangan, sementara kepemilikan institusional dan komite audit tidak berpengaruh terhadap ketepatan waktu pelaporan keuangan. Opini audit tidak mampu memperkuat pengaruh profitabilitas, ukuran perusahaan, kepemilikan institusional, dan komite audit terhadap ketepatan waktu pelaporan keuangan.

Kata kunci: Profitabilitas, ukuran perusahaan, kepemilikan institusional, komite audit, ketepatan waktu

\section{Role of Audit Opinion as A Moderator of the Effects of Profitability, Company Size, Institutional Ownership, and Audit Committee on the Accuracy of Financial Reporting Time}

\begin{abstract}
The purpose of this research is to find the role of audit opinion as a moderator of the effects of profitability, firm size, institutional ownership, and audit committee on the timeliness of financial reporting on manufacturing companies listed on the Indonesia Stock Exchange between 2012 and 2016. Purposive sampling was used in this research to obtain 96 sample manufacturing companies. The data analysis technique that was used in this research is logistic regression. The hypothesis testing showed that profitability and firm size positively affects the timeliness of financial reporting. Meanwhile, institutional ownership and audit committee does not affect the timeliness of financial reporting. Audit opinion cannot moderate the effect of profitability, firm size, institutional ownership, and audit committee on the timeliness of financial reporting.
\end{abstract}

Keywords: Profitability, firm size, institutional ownership, audit committee, audit opinion, timeliness 


\section{PENDAHULUAN}

Laporan keuangan merupakan gambaran kondisi suatu perusahaan karena memuat informasiinformasi dibutuhkan oleh pihak eksternal yang berkepentingan terhadap perusahaan. Laporan keuangan suatu perusahaan akan memiliki manfaat jika disampaikan secara akurat dan tepat waktu kepada para stakeholders sebagai dasar membuat keputusan. Hal ini menunjukkan betapa pentingnya ketepatan waktu pelaporan keuangan khususnya bagi perusahaan yang sudah go public, dimana diharuskan untuk menyusun laporan keuangan setiap periodenya.

Peraturan mengenai waktu pelaporan keuangan di Indonesia diatur pada oleh Bapepam-LK pada Peraturan Bapepam-LK Nomor X.K.2, Lampiran Keputusan Ketua Bapepam-LK Nomor KEP-346/ BL/2011 tentang Penyampaian Laporan Keuangan Berkala Emiten atau Perusahaan Publik. Perubahan Bapepam-LK menjadi Otoritas Jasa Keuangan (OJK) sampai saat ini belum mempengaruhi peraturan yang berlaku sebelumnya, sehingga peraturan yang digunakan masih menggunakan aturan yang dikeluarkan oleh Bapepam-LK. Pada peraturan tersebut yang dimaksud adalah laporan keuangan tahunan dan laporan keuangan tengah tahunan. Sesuai dengan peraturan tersebut, laporan keuangan tahunan disertai dengan laporan akuntan dalam rangka audit laporan keuangan, harus disampaikan kepada Bapepam-LK (OJK) selambatlambatnya pada akhir bulan ketiga setelah tanggal laporan keuangan.

Kewajiban tentang pelaporan keuangan perusahaan yang terdaftar di pasar modal juga diatur dalam Undang-Undang No. 8 Tahun1995 tentang Pasar Modal. Undang-undang tersebut menyebutkan semua perusahaan yang terdaftar di pasar modal wajib menyampaikan laporan keuangan berkala kepada Bapepam-LK (OJK) sesuai dengan batas waktu yang telah ditetapkan dalam Peraturan Bapepam-LK. Bagi perusahaan yang melanggar aturan tersebut akan dikenakan sanksi administrasi yang dapat berupa terguran tertulis, denda hingga penghentian sementara dari bursa.

Penyajian laporan keuangan secara tepat waktu merupakan aspek yang strategis untuk memperoleh keunggulan kompetitif dalam menunjang keberhasilan perusahaan. Banyak pihak yakin bahwa ketepatan waktu (timeliness) merupakan karakteristik penting bagi laporan keuangan. Informasi yang disajikan secara tidak tepat waktu akan mengurangi kemampuannya sebagai alat bantu prediksi bagi pemakainya dan informasi menjadi kurang relevan.

Seperti yang diberitakan neraca (www.neraca.co.id) untuk tahun buku 2012 terdapat 52 perusahaan yang belum melaporkan laporan keuangan tahunan auditannya. Tahun buku 2013 sebanyak 49 perusahaan terlambat menyampaikan laporan keuangan yang telah diaudit (www.kontan. co.id). Situs neraca juga memberitakan bahwa tahun buku 2014 sebanyak 52 perusahaan yang belum menyampaikan laporan keuangan audit. Bahkan menurut CNN Indonesia (www. cnnindonesia.com) PT Bursa Efek Indonesia mengganjar denda dan menghentikan sementara (suspensi) perdagangan saham 18 perusahaan karena belum menyampaikan laporan keuangan audit periode 31 Desember 2015. Menurut Jurnal Asia (www.jurnal asia.com) PT Bursa Efek Indonesia menghentikan sementara perdagangan efek (suspensi) terhadap 17 emiten karena belum menyampaikan laporan keuangan auditan periode 31 Desember 2016. Angka-angka tersebut menggambarkan bahwa ketepatan waktu penyampaian laporan keuangan masih menjadi kendala pada beberapa perusahaan publik di Indonesia.

Keterlambatan penyampaian laporan keuangan masih menjadi fenomena di Bursa Efek Indonesia. Hal ini dapat dilihat dari data tahun ke tahun dimana jumlah perusahaan yang terlambat menyampaikan laporan keuangan masih cukup banyak.

Berdasarkan dari hasil penelitian sebelumnya menunjukkan bahwa ketepatan waktu pelaporan keuangan dipengaruhi oleh profitabilitas (Dewi et al., 2016) senada dengan hasil penelitian dari Mahendra dan Putra (2014), Dewi dan Wirakusuma (2014), Sanjaya dan Wirawati (2016), Adebayo dan Adebiyi (2016) serta Pradipta dan Suryono (2017), ukuran perusahaan (Dewi et al., 2016) sejalan dengan penelitian Adebayo dan Adebiyi (2016), Sanjaya dan Wirawati (2016) serta Pradipta dan Suryono (2017), kepemilikan institusional (Mahendra dan Putra, 2014) sejalan dengan hasil penelitian Isani dan Ekowati (2015) dan Widyanjaya (2014), komite audit (Putri et al., 2015), likuiditas (Mahendra dan Putra 2014) senada dengan penelitian Dewi dan Wirakusuma (2014), opini audit (Kuswanto dan Manaf, 2015), ukuran KAP (Putri et al., 2015) sejalan dengan hasil penelitian Adebayo dan Adebiyi (2016), internal auditor (Putri et al., 2015), komisaris independen (Mahendra dan Putra, 2014), debt to equity ratio 
(Sanjaya dan Wirawati, 2016) sejalan dengan hasil penelitian Pradipta dan Suryono (2017), kualitas auditor (Pradipta dan Suryono, 2017), pergantian auditor (Sanjaya dan Wirawati, 2016), struktur kepemilikan (Sanjaya dan Wirawati, 2016).

Variabel yang tidak mempengaruhi ketepatan waktu adalah profitabilitas (Devi dan Suaryana, 2016), solvabilitas (Devi dan Suaryana, 2016), ukuran perusahaan (Mahendra dan Putra, 2014) sejalan dengan penelitian Dewi dan Hernawati (2015), Kuswanto dan Manaf (2015) serta Dewi dan Wirakusuma (2014), opini audit (Dewi dan Hernawati, 2015) sejalan dengan hasil penelitian Pradipta dan Suryono (2017), struktur kepemilikan (Dewi dan Hernawati 2015), komisaris independen (Dewi dan Wirakusuma, 2014), fee audit (Putriet et al., 2015), Leverage (Adebayo dan Adebiyi, 2016).

Berdasarkan penelitian di atas dapat dilihat bahwa masih ada beberapa variabel yang belum konsisten pengaruhnya yaitu pada variabel profitabilitas, ukuran perusahaan, opini audit, dan kepemilikan institusional. Maka dalam penelitian ini untuk menghindari perluasan masalah peneliti membatasi variabel yang akan diteliti hanya pada variabel profitabilitas, ukuran perusahaan, kepemilikan institusional, komite audit, dan opini audit sebagai variabel moderasi. Kebaruan dari penelitian ini adalah menggunakan variabel moderasi yaitu opini audit. Alasan peneliti menggunakan opini audit sebagai variabel moderasi karena opini audit diduga dapat memiliki pengaruh yang kuat dalam memoderasi hubungan beberapa variabel independen dengan variabel ketepatan waktu. Hasil penelitian Kuswanto dan Manaf (2015) menyatakan bahwa perusahaan yang mendapat opini audit dengan pendapat wajar tanpa pengecualian (unqualified opinion) dari auditor independen untuk laporan keuangannya cenderung akan lebih tepat waktu dalam penyampaian laporan keuangannya.

Profitabilitas merupakan kemampuan perusahaan memperoleh laba dalam satu periode akuntansi setelah dibandingkan dengan total aset maupun modal sendiri (Sartono, 2014). Tingkat kemampuan perusahaan menghasilkan keuntungan yang dilaporkan, diperkirakan dapat mempengaruhi tepat atau tidaknya waktu penyajian laporan keuangan kepada publik. Hal ini diungkapkan oleh Carslaw dan Kaplan dalam Putra dan Ramantha (2015) dimana perusahaan yang mengalami kerugian operasional telah meminta auditornya untuk menjadwalkan pengauditan lebih lambat dari biasanya, ini berarti profitabilitas mempengaruhi ketepatan waktu pelaporan keuangan. Penelitian yang dilakukan oleh Dewi dan Jusia (2013), Mahendra dan Putra (2014), Dewi dan Wirakusuma (2014), Sanjaya dan Wirawati (2016), Adebayo dan Adebiyi (2016) serta Pradipta dan Suryono (2017) menunjukkan bahwa profitabilitas berpengaruh positif terhadap ketepatan waktu pelaporan keuangan.

$\mathrm{H}_{1}$ : Profitabilitas berpengaruh positif terhadap ketepatan waktu pelaporan keuangan.

Ukuran perusahaan diukur berdasarkan besar atau kecilnya perusahaan dengan melihat total aset atau total penjualan yang dimiliki oleh perusahaan. Adebayo dan Adebiyi (2016) mengatakan bahwa perusahaan besar memiliki kinerja, manajemen, dan teknologi yang lebih baik sehingga lebih tepat waktu dalam menyampaikan laporan keuangannya. Hasil penelitian Wirakusuma dan Cindrawati (2011) menunjukkan bahwa ukuran perusahaan memiliki pengaruh signifikan dan memiliki jenis hubungan negatif terhadap rentang waktu penyelesaian laporan keuangan auditan, dengan kata lain memiliki hubungan negatif dengan keterlambatan penyelesaian penyajian laporan keuangan atau memiliki hubungan positif terhadap ketepatan waktu pelaporan keuangan pada perusahaan yang listing di Bursa Efek Indonesia. Hal ini sejalan dengan penelitian Sanjaya dan Wirawati (2016), Adebayo dan Adebiyi (2016) serta Pradipta dan Suryono (2017) yang menunjukkan bahwa ukuran perusahaan berpengaruh positif terhadap ketepatan waktu pelaporan keuangan.

$\mathrm{H}_{2}$ : Ukuran perusahaan berpengaruh positif terhadap ketepatan waktu pelaporan keuangan.

Kepemilikan institusional diduga mampu mempengaruhi ketepatan waktu pelaporan keuangan tahunan. Cahan dan Zhang (2006) mengemukakan kepemilikan institusional sebagai persentase suatu perusahaan yang memiliki investment banking, mutual funds, dan pensiun, asuransi, bank, dan reksa dana. Keberadaan investor institusional dapat menunjukkan mekanisme corporate governance yang kuat sehingga mampu memberikan pengawasan terhadap manajemen perusahaan. Beberapa penelitian terdahulu telah dilakukan oleh para peneliti lain untuk menguji hubungan ketepatan waktu dengan kepemilikan institusional antara lain Kadir (2011), Mahendra dan Putra (2014), Widyanjaya (2014) serta 
Isani dan Ekowati (2015) menunjukkan bahwa kepemilikan institusional berpengaruh positif terhadap ketepatan waktu pelaporan keuangan.

$\mathrm{H}_{3}$ : Kepemilikan institusional berpengaruh positif terhadap ketepatan waktu pelaporan keuangan.

Dengan adanya anggota komite audit yang lebih dari satu, maka anggota komite audit akan berkolaborasi dan bekerja sama dalam hal peningkatan pengawasan terhadap aktivitas dewan direksi. Di Indonesia, pedoman pembentukan komite audit yang efektif menjelaskan bahwa anggota komite audit yang dimiliki oleh perusahaan sedikitnya terdiri dari 3 (tiga) orang, diketuai oleh komisaris independen dengan dua orang eksternal yang independen terhadap perusahaan serta menguasai dan memiliki latar belakang akuntansi dan keuangan (Komite Nasional Kebijakan Governance, 2006). Hal ini dikarenakan setiap anggota komite audit memiliki pengalaman dan pengetahuan terkait keuangan dan tata kelola perusahaan yang berbeda-beda. Penelitian yang dilakukan oleh Ika dan Ghazali (2012) serta Oussii dan Taktak (2018) menunjukkan komite audit berpengaruh positif terhadap ketepatan waktu pelaporan keuangan.

$\mathrm{H}_{4}$ : Komite audit berpengaruh positif terhadap ketepatan waktu pelaporan keuangan.

Perusahaan yang memiliki profitabilitas tinggi dapat dikatakan bahwa laporan keuangan perusahaan tersebut mengandung berita baik dan perusahaan yang mengalami berita baik cenderung menyerahkan laporan keuangannya tepat waktu (Dewi et al., 2016). Laporan keuangan yang mendapat opini audit wajar tanpa pengecualian (unqualified opinion) cenderung akan lebih tepat waktu dalam menyampaikan laporan keuangannya karena unqualified opinion merupakan good news dari auditor sehingga auditor tidak perlu melakukan prosedur tambahan dalam proses auditnya. Sebaliknya perusahaan akan cenderung tidak tepat waktu dalam menyampaikan laporan keuangannya apabila menerima opini selain unqualified opinion karena hal tersebut dianggap sebagai berita buruk ( $b a d$ news). Profitabilitas yang tinggi serta opini audit unqualified opinion dapat menambah percaya diri perusahaan dalam menyampaikan laporan keuangan secara tepat waktu. Hal ini sesuai dengan penelitian yang dilakukan oleh Saputra dan Ramantha (2017) bahwa opini audit mampu memperkuat pengaruh positif profitabilitas terhadap ketepatan waktu pelaporan keuangan.
$\mathrm{H}_{5}$ : Opini audit memperkuat pengaruh positif profitabilitas terhadap ketepatan waktu pelaporan keuangan.

Sanjaya dan Wirawati (2016), Adebayo dan Adebiyi (2016), dan Ohaka dan Akani (2017) dalam penelitian mereka menemukan bahwa ukuran perusahaan secara signifikan mempunyai hubungan dengan ketepatan waktu penyampaian laporan keuangan. Ukuran (proksi) yang mereka gunakan untuk variabel ukuran perusahaan ini adalah dengan total aset. Bukti empiris yang ada menunjukkan bahwa perusahaan yang memiliki aset yang lebih besar melaporkan lebih cepat dibandingkan dengan perusahaan yang memiliki aset yang lebih kecil. Mereka beragumen bahwa perusahaan yang memiliki sumber daya (aset) yang besar memiliki lebih banyak sumber informasi, lebih banyak staf akuntansi, adanya pengawasan dari investor, regulator dan sorotan masyarakat, maka hal ini memungkinkan perusahaan untuk melaporkan keuangan auditanya lebih cepat ke publik.

Perusahaan besar yang laporan keuangannya mendapat opini unqualified opinion dari auditor independen akan cenderung menyampaikan laporan keuangannya tepat waktu karena perusahaan besar mendapat perhatian khusus dari para stakeholder. Hal ini sesuai dengan penelitian yang dilakukan oleh Turel (2010) bahwa perusahaan yang memperoleh opini selain unqualified opinion cenderung lebih lama untuk menyampaikan laporan keuangan dibandingkan perusahaan yang memperoleh opini unqualified opinion. Oleh karena itu, perusahaan besar saja tidak cukup menjamin akan menyampaikan laporan keuangan secara tepat waktu, melainkan perusahaan harus mendapat opini unqualified opinion agar semakin tepat waktu.

$\mathrm{H}_{6}$ : Opini audit memperkuat pengaruh positif ukuran perusahaan terhadap ketepatan waktu pelaporan keuangan.

Menurut Machmud dan Djakman (2008) kepemilikan institusional merupakan pemegang saham terbesar sehingga memungkinkan untuk melakukan monitoring terhadap manajemen. Penyusunan laporan keuangan dipengaruhi oleh kepemilikan modal oleh pihak luar (Boediono, 2005). Hasil penelitian yang dilakukan oleh Harnida (2005) bahwa ada hubungan antara kepemilikan institusional dengan ketepatan waktu pelaporan keuangan, sedangkan hasil penelitian Mouna dan Anis (2013) 
menyatakan bahwa kepemilikan institusional tidak berpengaruh signifikan terhadap ketepatan waktu pelaporan keuangan.

Perusahaan yang dimiliki oleh institusi dan mendapat opini audit unqualified opinion dalam laporan keuangannya akan berusaha mempercepat penerbitan laporan keuangan, karena itu adalah berita baik buat pemegang saham. Selain itu, tekanan dari pemegang saham mayoritas membuat perusahaan menyampaikan laporan keuangan secara tepat waktu. Kuswanto dan Manaf (2015) menyatakan bahwa perusahaan yang memperoleh opini unqualified opinion dari auditor independen cenderung lebih tepat waktu dalam menyampaikan laporan keuangannya.

$\mathrm{H}_{7}$ : Opini audit memperkuat pengaruh positif kepemilikan institusional terhadap ketepatan waktu pelaporan keuangan.

Komite audit merupakan komite bentukan dewan komisaris yang tanggung jawabnya kepada dewan komisaris. Komite audit juga membantu dewan komisaris untuk mengawasi proses mengolah informasi keuangan oleh manajemen untuk meningkatkan kualitas laporan keuangan (Ika dan Ghazali, 2012). Keefektifan komite audit akan meningkat seiring dengan bertambahnya ukuran komite audit, karena mereka memiliki sumber daya yang memadai untuk menghadapi masalah perusahaan (Oussii dan Taktak, 2018). Hal tersebut sejalan dengan Naimi et al.,(2010) semakin banyak anggota komite audit dan semakin banyak pertemuan yang dilakukan akan meningkatkan ketepatan waktu pelaporan keuangan. Hasil penelitian yang dilakukan oleh Yadirichukwu dan Ebimobowei (2013) menyatakan bahwa ada pengaruh signifikan antara komite audit independen dan keahlian komite audit terhadap ketepatwaktuan pelaporan keuangan. Sejalan dengan penelitian yang dilakukan oleh Ika dan Ghazali (2012) bahwa komite audit memiliki pengaruh positif terhadap ketepatan waktu pelaporan keuangan.

Karena adanya pengawasan yang dilakukan oleh komite audit sehingga kualitas laporan keuangan menjadi meningkat dan opini yang diberikan oleh auditor independen atas laporan keuangan menjadi unqualified opinion. Unqualified opinion ini akan mempengaruhi sikap komite audit untuk mendorong manajemen dalam mempercepat penyampaian laporan keuangan agar tepat waktu. Menurut Kuswanto dan Manaf (2015) ketepatan waktu pelaporan keuangan berhubungan dengan pendapat auditor, dimana auditor yang memberikan pendapat unqualified opinion menjadikan berita baik bagi perusahaan sehingga akan tepat waktu dalam menyampaikan laporan keuangannya.

$\mathrm{H}_{8}$ : Opini audit memperkuat pengaruh positif komite audit terhadap ketepatan waktu pelaporan keuangan.

\section{METODE PENELITIAN}

Penelitian ini adalah penelitian yang bersifat pengujian hipotesis karena dari hasil analisis data akan mencari tahu penyebab atau alasan yang mempengaruhi variabel independen terhadap variabel dependen. Data yang digunakan dalam penelitian ini adalah laporan keuangan perusahaan manufaktur yang terdaftar di Bursa Efek Indonesia periode 2012 - 2016. Strategi penelitian ini adalah menggunakan data sekunder dimana tersebut diperoleh dengan mengunduh pada website Bursa Efek Indonesia.

Ketepatan waktu adalah tersedianya informasi bagi pembuat keputusan pada saat dibutuhkan sebelum informasi tersebut kehilangan kekuatan untuk mempengaruhi keputusan (Suwardjono, 2010:170). Ketepatan waktu diukur menggunakan variabel dummy. Kategori perusahaan yang menyampaikan laporan keuangan tepat waktu diberi nilai dummy 1 dan kategori perusahaan yang menyampaikan laporan keuangan tidak tepat waktu diberi nilai dummy 0 .

Profitabilitas merupakan salah satu indikator keberhasilan perusahaan untuk dapat menghasilkan laba sehingga semakin tinggi profitabilitas maka semakin tinggi kemampuan perusahaan untuk menghasilkan laba bagi perusahaannya (Kuswanto dan Manaf, 2015). Profitabilitas diukur melalui Return On Asset (ROA) yaitu dengan perbandingan laba bersih setelah pajak dengan rata-rata total aset.

$$
\text { ROA }=\frac{\text { Laba bersih setelah pajak }}{\text { Rata }- \text { rata total aset }}
$$

Ukuran perusahaan adalah suatu skala dimana dapat diklasifikasikan besar kecil perusahaan menurut berbagai cara, antara lain total nilai aset, total penjualan, kapitalisasi pasar, jumlah tenaga kerja dan sebagainya (Putra dan Thohiri, 2013).

$$
\text { Size }=\operatorname{Ln}(\text { Total Aset })
$$

Kepemilikan institusional adalah kepemilikan saham suatu perusahaanoleh institusi keuangan 
seperti perusahaan asuransi, bank, dana pensiun, daninvestment banking (Siregar dan Utama, 2005).

$$
K I=\frac{\text { Jumlah saham institusi }}{\text { Jumlah saham beredar }} \times 100 \%
$$

Komite audit adalah komite yang dibentuk oleh dewan komisaris dan bertanggung jawab kepada dewan komisaris dalam membantu melaksanakan fungsi dewan komisaris, yang anggotanya diangkat dan diberhentikan oleh dewan komisaris, komite audit bertindak secara independen dalam melaksanakan tugas dan fungsi dewan komisaris(Putri et al., 2015). Dimensi yang dapat diukur dari komite audit adalah banyaknya jumlah anggota komite audit di perusahaan.

Opini audit adalah pendapat auditor tentang laporan keuangan yang telah diauditnya (Islahuzzaman, 2012:292). Opini audit diukur menggunakan variabel dummy. Kategori perusahaan yang mendapat opini wajar tanpa pengecualian (unqualified opinion) dari auditor diberi nilai dummy 1 dan kategori perusahaan yang mendapat opini selain unqualified opinion diberi nilai dummy 0 .

Populasi dari penelitian ini adalah perusahaan manufaktur di Bursa Efek Indonesia periode 2012 2016. Jumlah perusahaan manufaktur pada periode tersebut sebanyak 133 perusahaan.Sampel diperoleh dengan menggunakan teknik purposive sampling sehingga sampel yang didapat sebanyak 96 perusahaan dengan 480 pengamatan. Alat analisis yang digunakan adalah menggunakan regresi logistik.

\section{HASIL DAN PEMBAHASAN}

Data diperoleh dari laporan keuangan perusahaan manufaktur tahun 2012 sampai dengan tahun 2016 dapat diketahui bahwa jumlah perusahaan yang terdaftar di Bursa Efek Indonesia sebanyak 133 perusahaan. Dari jumlah tersebut, perusahaan yang dapat diambil sebagai sampel penelitian ini adalah sebanyak 96 perusahaan. Sumber data berasal dari website Bursa Efek Indonesia (www.idx.co.id) dan Indonesian Capital Market Electronic Library (ICaMEL). Penentuan jumlah sampel dilakukan dengan purposive sampling, dengan kriteria pengambilan sampel yang telah ditentukan.

Berdasarkan seleksi pemilihan sampel sesuai dengan kriteria yang telah ditentukan, maka dapat diperoleh 96 perusahaan setiap tahun yang memenuhi kriteria sampel, sehingga sampel yang digunakan dalam penelitian ini adalah sebanyak 480 (96x5) perusahaan yang dapat dilihat dalam Tabel 1 dan 2 .

\section{Tabel 1. Kriteria Pengambilan Sampel}

\begin{tabular}{clc}
\hline No & \multicolumn{1}{c}{ Kriteria Pengambilan Sampel } & Jumlah \\
\hline 1 & $\begin{array}{l}\text { Perusahaan manufaktur yang terdaftar di Bursa Efek Indonesia sejak } \\
\text { periode 2012 - 2016 }\end{array}$ & 133 \\
2 & $\begin{array}{l}\text { Perusahaan manufaktur yang tidak menerbitkan laporan keuangan audited } \\
\text { dalam mata uang Rupiah per 31 Desember 2012 - 31 Desember 2016 }\end{array}$ & (29) \\
3 & $\begin{array}{l}\text { Perusahaan manufaktur yang pernah mengalami delisting selama periode } \\
\text { 2013 - 2016 } \\
\text { Perusahaan manufaktur yang pernah mengalami perubahan kelompok } \\
\text { usaha periode 2013 - 2016 }\end{array}$ & Jumlah Sampel \\
$\quad$ Jumlah Observasi 96 (perusahaan) x 5 (2012-2016) tahun
\end{tabular}

Sumber: Data diolah, 2018

Dari seluruh sampel penelitian yang terdiri dari 96 perusahaan selama periode $2012-2016$, sebagian besar telah menyampaikan laporan keuangannya secara tepat waktu dengan frekuensi sebanyak 345 sampel (71,9 persen). Sementara jumlah laporan keuangan yang tidak disampaikan secara tepat waktu sebanyak 135 sampel (28,1 persen).

Tabel 2. Analisis Statistik Deskriptif Variabel Ketepatan Waktu

\begin{tabular}{llrrrr}
\hline \multicolumn{5}{c}{ Ketepatan Waktu (Y) } \\
& & & & Cumulative \\
& & Frequency & Percent & Valid Percent & Percent \\
\hline \multirow{2}{*}{ Valid } & Tidak Tepat Waktu & 135 & 28,1 & 28,1 & 28,1 \\
& Tepat Waktu & 345 & 71,9 & 71,9 & 100,0 \\
& Total & 480 & 100,0 & 100,0 & \\
\hline
\end{tabular}

Sumber: Data diolah, 2018 
Tabel 3. Analisis Statistik Deskriptif Variabel Opini Audit

\begin{tabular}{llrrrr}
\hline \multicolumn{5}{c}{ Opini Audit (Z) } \\
\hline & & & Valid & \multicolumn{2}{c}{ Cumulative } \\
Valid & Frequency & Percent & Percent & \multicolumn{1}{c}{ Percent } \\
\hline & Selain WTP & 83 & 17,3 & 17,3 & 17,3 \\
& WTP & 397 & 82,7 & 82,7 & 100,0 \\
& Total & 480 & 100,0 & 100,0 & \\
\hline
\end{tabular}

Sumber: Data diolah, 2018

Opini audit adalah pendapat yang diberikan oleh akuntan publik atau auditor independen atas laporan keuangan yang diperiksanya. Dari seluruh observasi dalam penelitian ini, sebagian besar laporan keuangan perusahaan manufaktur periode 2012 - 2016 mendapat opini audit wajar tanpa pengecualian (unqualified opinion) dengan frekuensi sebanyak 397 sampel (82,7 persen). Sedangkan, sisanya laporan keuangan yang mendapat opini audit selain wajar tanpa pengecualian sebanyak 83 sampel $(17,3$ persen).

Tabel 4. Analisis Statistik Deskriptif Variabel Kuantitatif

\begin{tabular}{lcrrrr}
\hline & N & Minimum & Maximum & \multicolumn{1}{c}{ Mean } & Std. Deviation \\
\hline Profitabilitas (X1) & 480 & $-95,45$ & 40,38 & 4,9146 & 10,71103 \\
Ukuran Perusahaan (X2) & 480 & 21,07 & 33,20 & 28,0587 & 1,68108 \\
Kepemilikan Institusional (X3) & 480 &, 00 & 98,96 & 66,4658 & 23,83919 \\
Komite Audit (X4) & 480 & 0 & 5 & 3,07 &, 470 \\
Valid N (listwise) & 480 & & & & \\
\hline
\end{tabular}

Sumber: Data diolah, 2018

Nilai profitabilitas (ROA) terendah adalah -95,45 yang terjadi pada perusahaan PT Anugerah Kagum Karya Utama Tbk (AKKU) pada tahun 2015. Sedangkan nilai ROA tertinggi adalah 40,38 yang terjadi pada perusahaan PT Unilever Indonesia Tbk (UNVR) pada tahun 2012. Nilai ukuran perusahaan terendah adalah 21,07 yang terjadi pada perusahaan PT Anugerah Kagum Karya Utama Tbk (AKKU) pada tahun 2015. Sedangkan nilai ukuran perusahaan tertinggi adalah 33,20 yang terjadi pada perusahaan PT Astra Internasional Tbk (ASII) pada tahun 2016. Nilai kepemilikan institusional terendah adalah 0,00 persen yang terjadi pada perusahaan antara lain PT Semen Indonesia Tbk (SMGR) pada tahun 2012 2016, PT Intanwijaya Internasional Tbk (INCI) pada tahun 2012 - 2016, PT Kimia Farma Tbk (KAEF) pada tahun 2012 - 2016, PT Saranacentral Bajatama Tbk (BAJA) pada tahun 2012 - 2016, PT Indofarma
Tbk (INAF) pada tahun 2012 - 2014, PT Siwani Makmur Tbk (SIMA) pada tahun 2015 - 2016, dan PT Jaya Pari Steel Tbk (JPRS) pada tahun 2016. Sedangkan nilai kepemilikan institusional tertinggi adalah 98,96 persen yang terjadi pada perusahaan PT Bentoel Internasional Investama Tbk (RMBA) pada tahun 2012-2014. Jumlah anggota komite audit tertinggi adalah 5 orang yaitu pada perusahaan PT Charoen Pokphand Indonesia Tbk (CPIN) pada tahun 2012 - 2016. Sedangkan jumlah anggota komite audit terendah adalah 0 orang (tidak ada) yaitu pada perusahaan PT Wismilak Inti Makmur Tbk (WIIM) pada tahun 2012. PT Wismilak Inti Makmur Tbk baru membentuk komite audit pada tahun 2013 sehingga pada tahun 2012 belum memiliki anggota komite audit.

Uji Kesesuaian Model. Adapun hasil pengujian Hosmer and Lemeshow Test untuk kedua tahap tersebut adalah:

Tahap 1 (Tanpa Moderasi):

\begin{tabular}{|c|c|c|c|}
\hline Step & Chi-square & $\mathrm{df}$ & Sig. \\
\hline 1 & 14,660 & 8 &, 066 \\
\hline
\end{tabular}

Berdasarkan tabel diatas diketahui bahwa pada kedua tahap tersebut, nilai signifikansi uji lebih besar dari 0,05 yaitu 0,066 untuk tahap 1 dan 0,150 untuk tahap 2. Hal ini berarti untuk kedua tahap $\mathrm{H}_{0}$ diterima sehingga dapat disimpulkan bahwa model pada kedua tahap tersebut sudah mampu menjelaskan data. Oleh karena tidak ada perbedaan yang signifikan antara klasifikasi yang diprediksi dengan klasifikasi yang diamati maka dapat dilanjutkan ke tahap analisis selanjutnya. 
Tahap 2 (Dengan Moderasi):

Tabel 6. Hosmer and Lemeshow Test Dengan Moderasi

\begin{tabular}{lcccr}
\hline Step & Chi-square & df & & Sig. \\
\hline 1 & 12,029 & & 8 &, 150 \\
\hline
\end{tabular}

Sumber: Data diolah, 2018

Uji Simultan atau Model. Adapun hasil pengujian Omnibus Testof Model Coefficients untuk kedua tahap tersebut adalah:

Tahap 1 (Tanpa Moderasi):

Tabel 7. Omnibus Test of Model Coefficients Tanpa Moderasi

\begin{tabular}{llrrr}
\hline & & Chi-square & df & \multicolumn{2}{c}{ Sig. } \\
\hline Step 1 & Step & 42,096 & 4 &, 000 \\
& Block & 42,096 & 4 &, 000 \\
& Model & 42,096 & 4 &, 000 \\
\hline
\end{tabular}

Sumber: Data diolah, 2018

Berdasarkan tabel diatas diketahui bahwa pada sehingga dapat disimpulkan bahwa minimal terdapat kedua tahap tersebut nilai signifikansi uji lebih kecil dari 0,05 yaitu 0,000 untuk tahap 1 dan 0,000 untuk tahap 2. Hal ini berarti untuk kedua tahap $\mathrm{H}_{0}$ ditolak satu variabel yang berpengaruh signifikan terhadap ketepatan waktu pelaporan keuangan.

Tahap 2 (Dengan Moderasi):

Tabel 8. Omnibus Test of Model Coefficients Dengan Moderasi

\begin{tabular}{|c|c|c|c|c|}
\hline & & Chi-square & df & Sig. \\
\hline \multirow[t]{3}{*}{ Step 1} & Step & 89,725 & 9 & ,000 \\
\hline & Block & 89,725 & 9 & ,000 \\
\hline & Model & 89,725 & 9 &, 000 \\
\hline
\end{tabular}

Sumber: Data diolah, 2018

Uji Parsial. Adapun hasil pengujian Wald Test untuk kedua tahap tersebut adalah:

Tahap 1 (Tanpa Moderasi):

Tabel 9. Variables in the Equation Tanpa Moderasi

\begin{tabular}{llrr}
\hline & & & \\
& & & \\
Step 1 $^{\text {a }}$ & Profitabilitas (X1) &, 036 &, 004 \\
& Ukuran Perusahaan (X2) &, 361 &, 000 \\
& Kepemilikan Institusional (X3) &, 800 \\
Komite Audit (X4) &,- 001 &, 215 \\
Constant &,- 311 &, 000 \\
\hline Sumber: Data diolah, 2018 & $-8,237$ &
\end{tabular}

Berdasarkan kedua tabel di atas, dapat dilihat bahwa untuk tahap 1 maupun tahap 2 hanya variabel profitabilitas dan ukuran perusahaan yang berpengaruh terhadap ketepatan waktu pelaporan keuangan. Terlihat juga bahwa opini audit sebagai pemoderasi hanya mampu memperkuat pengaruh negatif profitabilitas dan ukuran perusahaan terhadap ketepatan waktu pelaporan keuangan. Sementara opini audit tidak mampu memperkuat pengaruh kepemilikan institusional dan komite audit terhadap ketepatan waktu pelaporan keuangan. 
Tahap 2 (Dengan Moderasi):

Tabel 10. Variables in the Equation Dengan Moderasi

\begin{tabular}{llrr}
\hline & & & \\
\hline Step 1 & & \\
& Profitabilitas (X1) &, 104 & Sig. \\
& Ukuran Perusahaan (X2) &, 853 &, 002 \\
Kepemilikan Institusional (X3) &,- 011 &, 285 \\
Komite Audit (X4) &,- 924 &, 175 \\
Opini Audit (Z) & 15,221 &, 041 \\
X1*Z &,- 084 &, 021 \\
X2*Z &,- 594 &, 047 \\
X3*Z &, 012 &, 320 \\
X4*Z &, 788 &, 290 \\
Constant & $-20,874$ &, 003 \\
\hline
\end{tabular}

Sumber: Data diolah, 2018

Uji Koefisien Determinasi. Adapun hasil output SPSS untuk koefisien determinasi adalah sebagai berikut:

Tahap 1 (Tanpa Moderasi):

Tabel 11. Uji Koefisien Determinasi Tanpa Moderasi

\begin{tabular}{lrrrr}
\hline Step & -2 Log likelihood & $\begin{array}{c}\text { Cox \& Snell R } \\
\text { Square }\end{array}$ & \multicolumn{2}{c}{$\begin{array}{c}\text { Nagelkerke R } \\
\text { Square }\end{array}$} \\
\hline 1 & $528,269^{\mathrm{a}}$ &, 084 &, 121 \\
\hline
\end{tabular}

Sumber: Data diolah, 2018

Nilai Nagelkerke $R$ Square sebesar 0,121 persen dan sisanya sebesar 87,9 persen dipengaruhi berarti ketepatan waktu pelaporan keuangan mampu oleh variabel lain di luar model. dijelaskan oleh variabel independen sebesar 12,1

Tahap 2 (Dengan Moderasi):

Tabel 12. Uji Koefisien Determinasi Dengan Moderasi

\begin{tabular}{lrrrr}
\hline & & Cox \& Snell R & \multicolumn{2}{c}{ Nagelkerke R } \\
Step & -2 Log likelihood & Square & Square \\
\hline 1 & $480,640^{\mathrm{a}}$ &, 170 &, 245 \\
\hline
\end{tabular}

Sumber: Data diolah, 2018

Nilai Nagelkerke $R$ Square dengan moderasi sebesar 0,245 berarti ketepatan waktu pelaporan keuangan mampu dijelaskan oleh variabel independen yang dimoderasi sebesar 24,5 persen dan sisanya sebesar 75,5 persen dipengaruhi oleh variabel lain di luar model. Uji Tingkat Ketepatan Prediksi Model. Hasil uji tingkat ketepatan prediksi model dapat Model 1 (Tanpa Moderasi): ditunjukkan pada tabel berikut:

Tabel 13. Classification Table Tanpa Moderasi

\begin{tabular}{|c|c|c|c|c|c|}
\hline & \multirow{3}{*}{\multicolumn{2}{|c|}{ Observed }} & \multirow{2}{*}{\multicolumn{2}{|c|}{$\begin{array}{l}\text { Predicted } \\
\text { Ketepatan Waktu (Y) } \\
\text { Tidak Tepat }\end{array}$}} & \multirow{3}{*}{$\begin{array}{c}\text { Percentage } \\
\text { Correct }\end{array}$} \\
\hline & & & & & \\
\hline & & & Waktu & Tepat Waktu & \\
\hline \multirow[t]{3}{*}{ Step 1} & Ketepatan Waktu (Y) & Tidak Tepat Waktu & 14 & 121 & 10,4 \\
\hline & & Tepat Waktu & 8 & 337 & 97,7 \\
\hline & Overall Percentage & & & & 73,1 \\
\hline
\end{tabular}

Sumber: Data diolah, 2018 
Terlihat pada classification table bahwa model tahap 1 mampu memprediksi dengan tingkat akurasi sebesar 73,1 persen, merupakan tingkat akurasi yang cukup baik dalam pengklasifikasian data.

Model 2 (Dengan Moderasi):

Tabel 14. Classification Table Dengan Moderasi

\begin{tabular}{|c|c|c|c|c|c|}
\hline & \multirow[b]{2}{*}{ Observed } & & \multicolumn{3}{|c|}{$\begin{array}{l}\text { Predicted } \\
\text { Ketepatan Waktu (Y) }\end{array}$} \\
\hline & & & $\begin{array}{l}\text { Tidak Tepat } \\
\text { Waktu }\end{array}$ & Tepat Waktu & $\begin{array}{l}\text { Percentage } \\
\text { Correct }\end{array}$ \\
\hline \multirow[t]{3}{*}{ Step 1} & Ketepatan Waktu (Y) & Tidak Tepat Waktu & 41 & 94 & 30,4 \\
\hline & & Tepat Waktu & 14 & 331 & 95,9 \\
\hline & Overall Percentage & & & & 77,5 \\
\hline
\end{tabular}

Sumber: Data diolah, 2018

Terlihat pada classification table bahwa model tahap 2 mampu memprediksi dengan tingkat akurasi sebesar 77,5 persen, merupakan tingkat akurasi yang cukup baik dalam pengklasifikasian data.
Interpretasi Model. Model regresi logistik dapat dibentuk dengan melihat pada nilai estimasi parameter dalam Variables in the Equation.

Model 1 (Tanpa Moderasi):

$$
\operatorname{Ln} \frac{T L}{1-T L}=-8,237+0,036 \mathrm{X}_{1}+0,361 \mathrm{X}_{2}-0,001 \mathrm{X}_{3}-0,311 \mathrm{X}_{4}+\varepsilon
$$

Model 2 (Dengan Moderasi):

$$
\begin{aligned}
\operatorname{Ln} \frac{T L}{1-T L}= & -20,874+0,104 \mathrm{X}_{1}+0,853 \mathrm{X}_{2}-0,011 \mathrm{X}_{3}-0,924 \mathrm{X}_{4}+15,221 . \mathrm{Z}- \\
& 0,084 \mathrm{X}_{1} * \mathrm{Z}-0,594 \mathrm{X}_{2} * \mathrm{Z}+0,012 \mathrm{X}_{3} * \mathrm{Z}+0,788 \mathrm{X}_{4} * \mathrm{Z}+\varepsilon
\end{aligned}
$$

Hipotesis pertama yang diajukan dalam penelitian ini adalah profitabilitas berpengaruh positif terhadap ketepatan waktu pelaporan keuangan. Berdasarkan hasil pengujian hipotesis untuk kedua model tersebut dilihat pada tabel model 1 dan model 2 di atas dapat diketahui bahwa profitabilitas memiliki nilai koefisien regresi positif sebesar 0,036 dengan nilai signifikansi $0,004<0,05$ pada pengujian tahap 1. Sedangkan pengujian tahap 2 koefisien regresi sebesar 0,104 dengan nilai signifikansi 0,002<0,05. Sehingga dapat disimpulkan bahwa profitabilitas berpengaruh positif terhadap ketepatan waktu pelaporan keuangan. Hasil penelitian ini sejalan dengan penelitian Dewi dan Jusia (2013), Mahendra dan Putra (2014), Dewi dan Wirakusuma (2014), Sanjaya dan Wirawati (2016), Adebayo dan Adebiyi (2016) serta Pradipta dan Suryono (2017) yang menunjukkan bahwa profitabilitas berpengaruh positif terhadap ketepatan waktu pelaporan keuangan.

Hipotesis kedua yang diajukan dalam penelitian ini adalah ukuran perusahaan berpengaruh positif terhadap ketepatan waktu pelaporan keuangan. Berdasarkan hasil pengujian hipotesis untuk kedua model tersebut dilihat pada tabel model 1 dan model 2 di atas dapat diketahui bahwa ukuran perusahaan memiliki nilai koefisien regresi positif sebesar 0,361 dengan nilai signifikansi $0,000<0,05$ pada pengujian tahap 1. Sedangkan pengujian tahap 2 koefisien regresi sebesar 0,853 dengan nilai signifikansi 0,003 $<0,05$. Sehingga dapat disimpulkan bahwa ukuran perusahaan berpengaruh positif terhadap ketepatan waktu pelaporan keuangan. Perusahaan yang memiliki sumber daya (aset) yang besar memiliki lebih banyak sumber informasi, lebih banyak staf akuntansi dan sistem informasi yang lebih canggih, memiliki sistem pengendalian internal yang kuat, adanya pengawasan dari investor, regulator, dan sorotan masyarakat. Hal ini memungkinkan perusahaan untuk melaporkan laporan keuangan auditannya lebih cepat ke publik. Hasil penelitian ini sejalan dengan penelitian yang dilakukan oleh Sanjaya dan Wirawati (2016), Adebayo dan Adebiyi (2016) serta Pradipta dan Suryono (2017) yang menunjukan 
bahwa ukuran perusahaan berpengaruh positif terhadap ketepatan waktu pelaporan keuangan.

Hipotesis ketiga yang diajukan dalam penelitian ini adalah kepemilikan institusional berpengaruh positif terhadap ketepatan waktu pelaporan keuangan. Berdasarkan hasil pengujian hipotesis untuk kedua model tersebut dilihat pada tabel model 1 dan model 2 di atas dapat diketahui bahwa kepemilikan institusional memiliki nilai koefisien regresi negatif sebesar -0,001 dengan nilai signifikansi 0,800>0,05 pada pengujian tahap 1 . Sedangkan pengujian tahap 2 koefisien regresi sebesar -0,011 dengan nilai signifikansi $0,285>0,05$. Sehingga dapat disimpulkan bahwa kepemilikan institusional tidak berpengaruh positif terhadap ketepatan waktupelaporan keuangan. Tidak berpengaruhnya kepemilikan institusional terhadap ketepatan waktu pelaporan keuangan diduga karena kurangnya pengawasan dari pihak institusi selaku pemegang saham dan pihak institusi lebih mementingkan angka dalam laporan keuangan terutama laba (profit) ketimbang waktu penyampaian laporan keuangan. Hasil penelitian ini sesuai dengan penelitian yang dilakukan oleh Putra dan Ramantha (2015) serta Dwiyani et al. (2017) yang menyatakan bahwa kepemilikan institusional tidak berpengaruh terhadap ketepatan waktu pelaporan keuangan.

Hipotesis keempat yang diajukan dalam penelitian ini adalah komite audit berpengaruh positif terhadap ketepatan waktu pelaporan keuangan. Berdasarkan hasil pengujian hipotesis untuk kedua model tersebut dilihat pada tabel model 1 dan model 2 di atas dapat diketahui bahwa komite audit memiliki nilai koefisien regresi negatif sebesar -0,311 dengan nilai signifikansi $0,215>0,05$ pada pengujian tahap 1. Sedangkan pengujian tahap 2 koefisien regresi sebesar -0,924 dengan nilai signifikansi 0,175>0,05. Sehingga dapat disimpulkan bahwa komite audit tidak berpengaruh positif terhadap ketepatan waktu pelaporan keuangan.. Hasil ini konsisten dengan penelitian Putra dan Ramantha (2015) yang memberikan hasil bahwa kurang efektifnya komite audit dalam mendorong perusahaan untuk menyerahkan laporan keuangan tepat waktu. Penelitian ini juga sejalan dengan penelitian Widyaswari dan Suardana (2014) dan Putri et al. (2015) yang tidak berhasil membuktikan pengaruh komite audit terhadap ketepatan waktu pelaporan keuangan. Penelitian tersebut menunjukkan bahwa ukuran komite audit bukan faktor penentu efektivitas komite audit. Semakin besar ukuran anggota komite audit akan mengakibatkan sulitnya membentuk jaringan komunikasi dan koordinasi yang baik antar anggota komite audit. Selain itu, akan cukup sulit untuk mengambil keputusan dari keterlibatan anggota komite audit yang berjumlah besar.

Hipotesis kelima yang diajukan dalam penelitian ini adalah opini audit memperkuat pengaruh positif profitabilitas terhadap ketepatan waktu pelaporan keuangan. Berdasarkan hasil pengujian hipotesis pada tahap 2 dapat dilihat bahwa opini audit yang memperkuat pengaruh positif profitabilitas terhadap ketepatan waktu pelaporan keuangan memiliki tingkat signifikansi sebesar $0,021<0,05$ namun dengan nilai koefisien regresi negatif sebesar $-0,084$ yang berlawanan dengan hipotesis. Sehinggadapat disimpulkan bahwa opini audit tidak mampu memperkuat pengaruh positif profitabilitas terhadap ketepatan waktu pelaporan keuangan. Opini audit tidak mampu memperkuat pengaruh positif profitabilitas terhadap ketepatan waktu pelaporan keuangan. Kesimpulan hasil pengujian regresi logistik untuk hipotesis kelima belum cukup bukti menyatakan bahwa opini audit memperkuat pengaruh positif profitabilitas terhadap ketepatan waktu pelaporan keuangan. Hal ini konsisten dengan penelitian yang dilakukan oleh Mellyana dan Astuti (2005) yang menyatakan bahwa opini audit tidak mampu memperkuat interaksi antara profitabilitas perusahaan dan ketepatan waktu pelaporan keuangan.

Hipotesis keenam yang diajukan dalam penelitian ini adalah opini audit memperkuat pengaruh positif ukuran perusahaan terhadap ketepatan waktu pelaporan keuangan. Berdasarkan hasil pengujian hipotesis pada tahap 2 dapat dilihat bahwa opini audit yang memperkuat pengaruh positif ukuran perusahaan terhadap ketepatan waktu pelaporan keuangan memiliki tingkat signifikansi sebesar 0,047< 0,05 namun dengan nilai koefisien regresi negatif sebesar -0,594 yang berlawanan dengan hipotesis. Sehingga dapat disimpulkan bahwa opini audit tidak mampu memperkuat pengaruh positif ukuran perusahaan terhadap ketepatan waktu pelaporan keuangan. Hasil penelitian ini sejalan dengan penelitian yang dilakukan oleh Saputra dan Ramantha (2017) yang menyebutkan bahwa opini audit tidak mampu memperkuat pengaruh ukuran perusahaan terhadap ketepatan waktu pelaporan keuangan. Dalam penelitian tersebut disebutkan bahwa terdapat kemungkinan opini audit bukan satu-satunya faktor yang menjadi pertimbangan perusahaan dalam menyampaikan laporan keuangan, dimana auditor 
dalam memberikan opininya tidak didasarkan pada ukuran perusahaan tersebut, melainkan berdasarkan kewajaran laporan keuangan yang dihasilkan perusahaan. Penelitian yang dilakukan oleh Turel (2010) menyatakan bahwa perusahaan yang memperoleh opini audit selain wajar tanpa pengecualian cenderung lebih lama untuk menyampaikan laporan keuangan dibandingkan perusahaan yang memperoleh opini wajar tanpa pengecualian. Oleh karena itu, semakin besar perusahaan belum cukup menjamin perusahaan menyampaikan laporan keuangan secara tepat waktu, melainkan perusahaan harus memperoleh opini wajar tanpa pengecualian agar semakin tepat waktu dalam menyampaikan laporan keuangan.

Hipotesis ketujuh yang diajukan dalam penelitian ini adalah opini audit memperkuat pengaruh positif kepemilikan institusional terhadap ketepatan waktu pelaporan keuangan. Berdasarkan hasil pengujian hipotesis pada tahap 2 dapat dilihat bahwa opini audit yang memperkuat pengaruh positif kepemilikan institusional terhadap ketepatan waktu pelaporan keuangan memiliki tingkat signifikansi sebesar $0,320>$ 0,05 dengan nilai koefisien regresi positif sebesar 0,012 . Sehingga dapat disimpulkan bahwa opini audit tidak mampu memperkuat pengaruh positif kepemilikan institusional terhadap ketepatan waktu pelaporan keuangan. Opini audit tidak mampu memperkuat pengaruh positif kepemilikan institusional terhadap ketepatan waktu pelaporan keuangan. Hasil pengujian regresi logistik untuk hipotesis ketujuh menyatakan bahwa opini audit memperkuat pengaruh positif kepemilikan institusional terhadap ketepatan waktu pelaporan keuangan. Penelitian ini sejalan dengan penelitian Mouna dan Anis (2013) yang menyatakan bahwa kepemilikan institusional tidak berpengaruh terhadap ketepatan waktu pelaporan keuangan. Tidak mampunya opini audit dalam memperkuat pengaruh kepemilikan institusional terhadap ketepatan waktu pelaporan keuangan, dikarenakan opini audit hanya menilai kewajaran laporan keuangan bukan faktor utama dalam penyampaian laporan keuangan. Dalam memberikan opini audit, akuntan publik tidak mendasarkan kewajaran laporan keuangan kepada persentase kepemilikan institusional. Selain itu, ditemukan juga beberapa perusahaan yang memiliki persentase kepemilikan institusional mencapai 98 persen dan memperoleh opini wajar tanpa pengecualian tetapi tidak menyampaikan laporan keuangan tepat waktu. Hal ini membuktikan bahwa besarnya persentase kepemilikan institusional dan opini wajar tanpa pengecualian bukan jaminan perusahaan tersebut akan menyampaikan laporan keuangan tepat waktu.

Hipotesis kedelapan yang diajukan dalam penelitian ini adalah opini audit memperkuat pengaruh positif komite audit terhadap ketepatan waktu pelaporan keuangan. Berdasarkan hasil pengujian hipotesis pada tahap 2 dapat dilihat bahwa opini audit yang memperkuat pengaruh positif komite audit terhadap ketepatan waktu pelaporan keuangan memiliki tingkat signifikansi sebesar 0,290>0,05 dengan nilai koefisien regresi positif sebesar 0,788 . Sehingga dapat disimpulkan bahwa opini audit tidak mampu memperkuat pengaruh positif komite audit terhadap ketepatan waktu pelaporan keuangan. Opini audit tidak mampu memperkuat pengaruh positif komite audit terhadap ketepatan waktu pelaporan keuangan. Hasil pengujian regresi logistik untuk hipotesis kedelapan menyatakan bahwa opini audit memperkuat pengaruh positif komite audit terhadap ketepatan waktu pelaporan keuangan. Berdasarkan hasil penelitian ini ditemukan bahwa semakin banyak anggota komite audit dan mendapat opini wajar tanpa pengecualian justru cenderung untuk tidak menyampaikan laporan keuangan secara tepat waktu. Bahkan terdapat beberapa perusahaan yang memiliki jumlah anggota komite audit 4 orang, dimana jumlah tersebut diatas standar minimal yang dipersyaratkan oleh Otoritas Jasa Keuangan (OJK) yaitu 3 orang. Hal ini tidak sesuai dengan konsep teori yang menyebutkan bahwa keefektifan komite audit akan meningkat seiring dengan bertambahnya ukuran komite audit karena memiliki sumber daya yang memadai untuk menghadapi masalah perusahaan (Oussii dan Taktak, 2018). Hasil penelitian ini sejalan dengan penelitian Putra dan Ramantha (2015) yang menunjukkan bahwa komite audit tidak berpengaruh terhadap ketepatan waktu pelaporan keuangan. Tidak mampunya opini audit dalam memoderasi pengaruh komite audit terhadap ketepatan waktu pelaporan keuangan diduga karena opini audit yang diberikan oleh akuntan publik hanya berdasarkan pada kewajaran atas laporan keuangan, bukan atas keefektifan fungsi dan jumlah anggota komite audit dalam mengawasi manajemen dalam hal pelaporan keuangan.

\section{SIMPULAN}

Berdasarkan analisis data dan pembahasan hasil penelitian, maka dapat disimpulkan bahwa profitabilitas 
dan ukuran perusahaan berpengaruh positif terhadap ketepatan waktu pelaporan keuangan, sedangkan kepemilikan institusional dan komite audit tidak berpengaruh terhadap ketepatan waktu pelaporan keuangan. Sementara itu, opini audit tidak mampu memperkuat pengaruh positif profitabilitas, ukuran perusahaan, kepemilikan institusional, dan komite audit terhadap ketepatan waktu pelaporan keuangan.

Untuk penelitian selanjutnya disarankan agar menggunakan variabel moderasi selain opini audit karena terbukti opini audit tidak dapat memperkuat pengaruh variabel independen terhadap ketepatan waktu pelaporan keuangan. Selain itu, disarankan untuk menambah variabel independen lain karena pada penelitian ini koefisien determinasi yang diperoleh sangat kecil.

\section{REFERENSI}

Adebayo, P. A. and W. K. Adebiyi. 2016. Effect of Firm Characteristics on The Timeliness of Corporate Financial Reporting: Evidence from Nigerian Deposit Money Banks. International Journal of Economics, Commerce and Management, Vol. IV No. 3: 369-381.

Al Daoud, K.A., K. N. I. K Ismail and N. A. Lode. 2014. The Timeliness of Financial Reporting among Jordanian Companies: Do Company and Board Characteristic, and Audit Opinion Matter?. Asian Social Science, Vol. 10 No. 13: 191-201.

Amri, A. B. 2014. Ini dia 49 emiten yang kena sanksi BEI. https://investasi.kontan. co.id/news/ini-dia49-emiten-yang-kena-sanksi-bei (diakses 10 Maret 2018).

Boediono, Gideon. 2005. Kualitas Laba: Studi Pengaruh Mekanisme Corporate Governance dan Dampak Manajemen Laba dengan Menggunakan Analisis Jalur. SNA VIII Solo.

Cahan, S. F. and W. Zhang. 2006. After Enron: Auditor Conservatism and Ex-Andersen Clients. The Accounting Review, Vol. 81 No. 1: 49-82.

Devi, N. L. L. S dan I. G. N. A. Suaryana. 2016. Pengaruh Profitabilitas dan Solvabilitas Terhadap Ketepatan Waktu dengan Reputasi Kantor Akuntan Publik sebagai Pemoderasi. E-Jurnal Akuntansi Universitas Udayana, Vol. 17 No. 1:395-425.

Dewi, S. P. dan Jusia. 2013. Faktor-Faktor yang Mempengaruhi Ketepatan Waktu Penyampaian Laporan Keuangan pada Perusahaan Real
Estate dan Property yang Terdaftar di BEI. Jurnal Akuntansi, Vol. XVII No. 3: 368-384.

Dewi, I. G. A. R. P dan M. G. Wirakusuma. 2014. Fenomena Ketepatwaktuan Informasi Keuangan dan Faktor yang Mempengaruhi di Bursa Efek Indonesia. E-Jurnal Akuntansi Universitas Udayana, Vol. 8 No. 1: 171-186.

Dewi, M. S. dan E. Hernawati. 2015. Pengaruh Opini Audit, Struktur Kepemilikan, dan Ukuran Perusahaan Terhadap Ketepatan Waktu Penyampaian Laporan Keuangan. Proceeding Seminar Nasional \& Call for Papers (SCA 5), Vol. 5 No. 1: 1-12.

Dewi, I. G. A. R. P., I. K. Yadnyana, dan I. P. Sudana. 2016. Pengaruh Profitabilitas dan Ukuran Perusahaan Terhadap Ketepat waktuan Penyampaian Laporan Keuangan dan Implikasinya pada Earnings Response Coefficient. E-Jurnal Ekonomi dan Bisnis Universitas Udayana, Vol. 5 No. 9: 3031-3056.

Dwiyani, S. A., I. D. N. Badera, dan I. P. Sudana. 2017. Faktor-Faktor Yang Mempengaruhi Ketepatwaktuan Penyajian Laporan Keuangan. E-Jurnal Ekonomi dan Bisnis Universitas Udayana, Vol. 6 No. 4:1451-1480.

Forum for Corporate Governance in Indonesia. 2000. Peranan Dewan Komisaris dan Komite Audit dalam Pelaksanaan Corporate Governance (Tata Kelola Perusahaan). https:// muhariefeffendi. files.wordpress.com/2009/12/ fcgi_booklet_ii.pdf(diakses 30 April 2018).

Ghozali, Imam. 2017. Ekonometrika: Teori, Konsep, dan Aplikasi dengan IBM SPSS 24. Semarang: Badan Penerbit Universitas Diponegoro.

. 2018. Aplikasi Analisis Multivariate Dengan Program IBM SPSS 25. Semarang: Badan Penerbit Universitas Diponegoro.

Godfrey, J., A. Hodgson, A. Tarca, J. Hamilton and S. Holmes. 2010. Accounting Theory. Australia: John Wiley \& Sons.

Gulec, O. F. 2017. Timeliness of Corporate Reporting in Developing Economic: Evidence from Turkey. Accounting and Management Information Systems, Vol. 16 No. 3: 219-239.

Harnida, Muthia. 2005. Faktor-Faktor yang Menentukan Kesegaran Penyerahan Laporan Keuangan (Tesis). Yogyakarta: Universitas Gadjah Mada. 
Ika, S. R. and N. A. M. Ghazali. 2012. Audit Commitee Effectiveness and Timeliness of Reporting: Indonesian Evidence. Managerial Auditing Journal, Vol. 27 No. 4: 403-424.

Isani, E. S. dan W. H. Ekowati. 2015. Pengaruh Kepemilikan Institusional dan Manajemen Laba Terhadap Ketepatan Waktu Pelaporan Keuangan (Studi pada Perusahaan Manufaktur di Bursa Efek Indonesia Periode 2011 - 2013). Jurnal Ilmiah Mahasiswa FEB Universitas Brawijaya, Vol. 4 No. 1: 1-18.

Islahuzzaman. 2012. Istilah-istilah Akuntansi \& Auditing. Jakarta: Bumi Aksara.

Jama'an. 2008. Pengaruh Mekanisme Corporate Governance dan Kualitas Kantor Akuntan Publik Terhadap Integritas Informasi Laporan Keuangan (Tesis). Semarang: Universitas Diponegoro.

Jurnal Asia. 2017. Belum Sampaikan Laporan Keuangan, BEI Suspensi 17 Saham Emiten. http://www.jurnalasia.com/bisnis/belumsampaikan-laporan-keuangan-bei-suspensi-17saham-emiten/ (diakses 11 Maret 2018).

Kadir, Abdul. 2011. Faktor-Faktor yang Berpengaruh Terhadap Ketepatan Waktu Pelaporan Keuangan Studi Empiris pada Perusahaan Manufaktur di Bursa Efek Jakarta. Jurnal Manajemen dan Akuntansi, Vol. 12 No. 1: 112.

KBBI. 2018. Kamus Besar Bahasa Indonesia (KBBI). https://kbbi.kemdikbud.go.id/entri/patuh (diakses 12 Maret 2018).

Komite Nasional Kebijakan Governance. 2016. Pedoman Umum Good Corporate Governance Indonesia. http://www.ecgi. org/codes/ documents/indonesia_cg_2006_id.pdf(diakses 30 April 2018).

Kuswanto, H. dan S. Manaf. 2015. Faktor-Faktor yang Mempengaruhi Ketepatan Waktu Penyampaian Laporan Keuangan ke Publik (Studi Empiris pada Perusahaan Manufaktur yang Terdaftar di Bursa Efek Indonesia Periode 2010 - 2013). Jurnal Ekonomi Manajemen Akuntansi, Vol. 22 No. 38: 1-18.

Machmud, N. dan C. D. Djakman. 2008. Pengaruh Struktur Kepemilikan terhadap Luas Pengungkapan Tanggung Jawab Sosial (CSR Disclosure) pada Laporan Tahunan Perusahaan: Studi Empiris pada Perusahaan Publik yang Tercatat di Bursa Efek Indonesia tahun 2006. SNA XI Pontianak.
Mahendra, I. B. K. Y dan I. N. W. A. Putra. 2014. Pengaruh Komisaris Independen, Kepemilikan Institusional, Profitabilitas, Likuiditas, dan Ukuran Perusahaan Terhadap Ketepatwaktuan. E-Journal Akuntansi Universitas Udayana, Vol. 9 No. 1: 180-199.

Margaretta, S. dan G. Soepriyanto. 2012. Penerapan IFRS dan Pengaruhnya Terhadap Keterlambatan Penyampaian Laporan Keuangan: Studi Perusahaan Manufaktur di Bursa Efek Indonesia Periode Tahun 2008 - 2010. Binus Business Review, Vol. 3 No. 2: 993-1009.

McGee, R. W. and X. Yuan. 2009. Corporate Governance and The Timeliness of Financial Reporting: An Empirical Study of The People's Republic of China. International Journal of Business, Accounting, and Finance, Vol. 3 No. 1: 19-27.

Mellyana, D. dan C. D. Astuti. 2005. Pengaruh Profitabilitas Perusahaan Terhadap Ketepatan Waktu Pelaporan Laporan Keuangan. Jurnal Akuntansi, Vol. 5 No. 3: 337-358.

Mouna, A. and J. Anis. 2013. Financial Reporting Delay and Investors Behavior: Evidence from Tunisia. International Journal of Management and Business Research, Vol. 3 No. 1: 57-67.

Nabhani, Ahmad. 2013. BEI Rilis 52 Emiten Telat Laporan Keuangan. http://www.neraca.co.id/ article/27070/bei-rilis-52-emiten-telat-laporankeuangan (diakses 10 Maret 2018).

Naimi, M. N, R. Shafie and W. N. Hussin. 2010. Corporate Governance and Audit Report Lag in Malaysia. Asian Academy of Management Journal of Accounting and Finance, Vol. 6 No. 2: 57-84.

Ohaka, J. and N. F. Akani. 2017. Timeliness and Relevance of Financial Reporting in Nigerian Quote Firms. Management and Organizational Studies, Vol. 4 No. 2: 55-62.

Oussii, A. A. And N. B. Taktak. 2018. Audit Comittee Effectiveness and Financial Reporting Timeliness: The Case of Tunisian Listed Companies. African Journal of Economic and Management Studies, Vol. 9 No. 1: 34-55.

Pasopati, Giras. 2016. Telat Sampaikan Lapkeu, BEI Suspensi Saham 18 Perusahaan. https:// www.cnnindonesia.com/ekonomi 20160630145045-92-142141/telat-sampaikanlapkeu-bei-suspensi-saham-18-perusahaan(diakses 9Maret 2018). 
Pradipta, D. M. dan B. Suryono. 2017. Analisis Faktor-Faktor Yang Mempengaruhi Ketepatan Waktu Pelaporan Keuangan. Jurnal Ilmu dan Riset Akuntansi, Vol. 6 No. 3: 1200-1216.

Putra, P. D. dan R. Thohiri. 2013. Analisis FaktorFaktor yang Mempengaruhi Ketepatan Waktu Penyampaian Laporan Keuangan pada Perusahaan yang Listing di Bursa Efek Indonesia Periode 2008 - 2010. Jurnal Bina Akuntansi IBBI, Vol. 18 No. 1: 28-39.

Putra, I. G. A. P dan I. W. Ramantha. 2015. Pengaruh Profitabilitas, Umur Perusahaan, Kepemilikan Institusional, Komisaris Independen, dan Komite Audit pada Ketepatwaktuan Publikasi Laporan Keuangan Tahunan. E-Jurnal Akuntansi Universitas Udayana, Vol. 10 No. 1: 199-213.

Putri, B. P., Kennedy, dan Y. Anisma. 2015. Pengaruh Karakteristik Komite Audit, Fee Audit, Ukuran KAP, dan Internal Auditor Terhadap Ketepatan Waktu (Timeliness) Pelaporan Keuangan. Jurnal FEKON,Vol. 2 No. 2: 1-15.

Sanjaya, I. M. D. M dan N. G. P. Wirawati. 2016. Analisis Faktor-Faktor Yang Mempengaruhi Ketepatan Waktu Pelaporan Keuangan Pada Perusahaan Manufaktur Yang Terdaftar di BEI. E-Jurnal Akuntansi Universitas Udayana, Vol. 15 No. 1: 17-26.

Saputra, K. W. S. dan I. W. Ramantha. 2017. Pengaruh Profitabilitas dan Ukuran Perusahaan Terhadap Ketepatan Waktu Pelaporan Keuangan dengan Opini Audit Sebagai Pemoderasi. E-Jurnal Akuntansi Universitas Udayana, Vol. 20 No. 2: 1592-1620.

Sartono, Agus. 2014. Manajemen Keuangan Teori dan Aplikasi. Yogyakarta: BPFE.

Sarwono, Jonathan. 2013. 12 Jurus Ampuh SPSS Untuk Riset Skripsi. Jakarta: Elex Media Komputindo.

Scott, W. R. 2015. Financial Accounting Theory. Toronto: Pearson Prentice Hall.

Sekaran, U. and R. Bougie. 2016. Research Methods for Business. New York: Wiley.

Siregar, S. V. dan S. Utama. 2005. Pengaruh Struktur Kepemilikan, Ukuran Perusahaan, dan Praktek Corporate Governance terhadap Pengelolaan Laba (Earnings Management). SNA VIII Solo.

Soares, M. dan M. N. Amin. 2016. Analisis FaktorFaktor yang Mempengaruhi Timeliness of
Financial Reporting dengan Reputasi Auditor sebagai Variabel Moderasi Atas Profitabilitas, Leverage, dan Umur Perusahaan (Studi Empiris Pada Perusahaan yang Terdaftar Di Bursa Efek Indonesia Periode 2010 - 2015). Jurnal Magister Akuntansi Trisakti, Vol. 3 No. 2: 121-146.

Srimindarti, C. 2008. Ketepatan Waktu Pelaporan Keuangan. Fokus Ekonomi (FE),Vol. 7 No. 1: 14-21.

Sufiyati. 2017. The Impact of Corporate Attributes on The Timeliness of Financial Reporting in Indonesia Stock Exchange. International Journal of Economic Perspectives, Vol. 11 No. 1: $1720-1730$.

Sugiyono. 2012. Metode Penelitian Bisnis. Bandung: Alfabeta.

Suwardjono. 2010. Teori Akuntansi (Perekayasaan Pelaporan Keuangan). Yogyakarta: BPFE.

Turel, A. 2010. Timeliness of Financial Reporting in Emerging Capital Markets: Evidence from Turkey. Istanbul University Journal of The School of Business Administration, Vol. 39 No. 2: 227-240.

Vuran, B. and B. Adiloglu. 2013. Is Timeliness of Corporate Financial Reporting Related to Accounting Variables? Evidence from Istanbul Stock Exchange. International Journal of Business and Social Science, Vol. 4 No. 6: 58-70.

Widyanjaya, B. R. 2014. Pengaruh Struktur Kepemilikan Perusahaan Terhadap Ketepatan Waktu Pelaporan Keuangan (Studi Empiris pada Perusahaan yang Terdaftar di Bursa Efek Indonesia Periode 2009 - 2012) (Tesis). Yogyakarta: Universitas Gadjah Mada.

Wirakusuma, M. G. dan P. M. Cindrawati. 2011. Pengaruh Profitabilitas, Solvabilitas, Reputasi Auditor, Ukuran Perusahaan, Kandungan Laba, dan Jenis Indrustri pada Ketidaktepatwaktuan Publikasi Laporan Keuangan di PT Bursa Efek Indonesia Periode 2007 - 2009. Jurnal Ilmiah Akuntansi dan Bisnis, Vol. 6 No. 2: 1-27.

Yadirichukwu, E. and A. Ebimobowei. 2013. Audit Committee and Timeliness of Financial Reports: Empirical Evidence from Nigeria. Journal of Economics and Sustainable Development, Vol. 4 No. 20: 14-25. 